\title{
Adherence to Self-Care Interventions for Depression or Anxiety: A Systematic Review
}

\author{
Russell Simco $^{\mathrm{a}}$, Jane McCusker ${ }^{\mathrm{a}, \mathrm{b}}$ and Maida Sewitch ${ }^{\mathrm{b}, \mathrm{c}}$ \\ ${ }^{\text {a}}$ St-Mary’s Research Centre, St-Mary’s Hospital, Canada \\ ${ }^{\mathrm{b}}$ Department of Epidemiology, Biostatistics and Occupational Health, McGill University, Canada \\ ${ }^{\mathrm{c}}$ Department of Medicine, McGill University, Canada
}

Corresponding author: Dr. J. McCusker, St. Mary’s Research Centre, Hayes Pavilion, Suite 3734, 3830 Avenue Lacombe, Montreal, Quebec, H3T 1M5, Canada. E-mail: jane.mccusker@mcgill.ca

Funding: This work was supported by the Fonds de la Recherche du Québec - Santé (FRQS) [grant \#16384] May 2009-April 2013.

Objectives: The study objective was to synthesise and describe adherence to intervention in published studies of supported self-care for depression or anxiety, and to identify participant characteristics associated with higher adherence.

Methods: We searched the databases EMBASE, MEDLINE, CINAHL, and PSYCINFO for the period from January 1986 until September 2010. Eligible studies reported on adherence to supported self-care interventions for depression or anxiety symptoms.

Results: We identified 40 studies of supported self-care interventions for depression and anxiety, of which 22 (55\%) reported any measure of adherence to the intervention. Among these 22 studies, 18 (82\%) reported the per cent of participants completing the entire self-care tool $(20 \%-93 \%$; Mean $=66 \%, S D 17), 13$ studies reported the amount of selfcare tools completed by the average participant $(50.6 \%-96.4 \%$; Mean $=$ $80 \%, S D$ 11.6). Four studies (18\%) reported the frequency of contacts with the self-care guide. Three (14\%) studies reported participant characteristics associated with adherence.

Conclusion: Overall, reported adherence levels to supported self-care interventions for depression and anxiety indicate a significant amount of patient involvement in these interventions. Routine reporting of adherence will improve our understanding of adherence to supported self-care interventions, and will allow researchers to link adherence with intervention outcome.

\section{Keywords}

Adherence, anxiety, depression, self-management, systematic review 


\section{INTRODUCTION}

Systematic reviews and meta-analyses suggest that self-care interventions can be effective in managing symptoms of depression and anxiety (Den Boer et al., 2004; Bower et al., 2001; Gellatly et al., 2007; Anderson et al., 2005). These interventions have been adopted as part of recommended models of management for these common mental health disorders (National Collaborating Centre for Mental Health, 2009, 2011). In addition to clinical effectiveness, the low cost of these interventions makes them an attractive alternative to conventional face-to-face therapy. Supported self-care interventions for depression and anxiety consist mainly of written or audio-visual components, often based on principles of cognitive behavioural therapy, supplemented with information on the treated illness (Den Boer et al., 2004; Bower et al., 2001; Gellatly et al., 2007; Anderson et al., 2005). Support components typically include short contacts (face-to-face, telephone or email) with personnel trained in the delivery of support for self-care interventions, referred to here as self-care guides (Gellatly et al., 2007, Newman et al., 2003). While there is substantial research examining the effectiveness of self-care interventions, little is known about adherence to these largely self-administered treatments.

Adherence is defined as the degree to which a 'person's behaviour - taking medication, following a diet, and/or executing lifestyle changes, corresponds with agreed recommendations from a health care provider' (Sabate, 2003: 3) Measures of adherence to self-care interventions for depression and anxiety typically include measures of use (e.g. completion of modules, frequency of use) of the self-care tools, and the frequency or length of contact with the self-care guides. Adherence to various medical and psychological interventions is often associated with participant characteristics; for example, illness severity, socioeconomic characteristics and social support (DiMatteo, 2004; DiMatteo et al., 2007). However, little is known about whether participant characteristics are associated with adherence to supported self-care interventions.

Research indicates that better adherence is associated with improved health outcomes across a range of treatments (DiMatteo et al., 2002; Kazantzis et al., 2000), while adherence has seldom been studied in the context of supported self-care interventions, the effects of adherence are expected to be similar in relation to treatment outcome: when patients use the self-care tool, they learn the techniques therein, and may therefore have better resulting health outcomes than those who do not read or use the self-care tool. It is therefore important to summarise the current adherence research in order to give researchers and health care providers benchmarks by which they might compare their own adherence data.

The present review aimed to identify original studies of supported self-care interventions for depression or anxiety, and to determine: the proportion that reported adherence to the intervention; the types of adherence measures used, participant characteristics associated with adherence, and the levels of adherence reported.. 


\section{METHODS}

The criteria for this review were fairly broad given a priori knowledge of the dearth of adherence reporting in supported self-care interventions for depression and anxiety. However, some pragmatic restrictions were made in order to reduce the breadth of the search process itself. As the study objectives are descriptive, randomised controlled trials as well as single-arm clinical trials, such as feasibility studies, were eligible for study inclusion.

\section{Search strategy}

Following consultation with a health sciences librarian, the search strategy devised was as follows: databases searched were MEDLINE, EMBASE, CINAHL and PSYCINFO, where the first three databases were searched using the Ovid platform. MeSH and text terms (as found in the title or abstract) were used to specify for:

1. illnesses: depressive disorders, depression, anxiety disorder, anxiety, chronic disease, chronic physical illness, diabetes, chronic obstructive pulmonary disease (COPD), asthma, stroke, heart disease and hypertension; and

2. interventions: self-care, self-management, self-help, minimal contact, brief therapy, self-efficacy, cognitive behavioural therapy, tele-health and telemedicine.

Adherence in studies of supported self-care is rarely (if ever) a primary outcome; in order to avoid an overly-specific search strategy, adherence terms were intentionally not specified. Restricting the search to include studies reporting adherence in the abstract or title would have eliminated most search results.

Studies were searched from January 1986 until September 2010, as 1986 has been previously used as a lower date limit in a Cochrane review of self-management interventions, beyond which the authors deemed it unlikely to find such types of interventions (Foster et al., 2007). Where available, filters were used to further specify the search strategy (e.g. therapeutic interventions; populations restricted to adults).

\section{Inclusion criteria}

Eligible study interventions met the following criteria: the intervention used some form of a self-care tool (a book, a manual or workbook, a computer or internet program) that was provided to participants. Participants were supported in the use of the tool by a self-care guide. The aim of the self-care intervention was to reduce symptoms of depression or anxiety. Studies reported any measure of adherence to the self-care tool (e.g. amount or frequency of use). Ratings of usefulness alone, however, were not considered adherence.

The professional background of the self-care guide was not restricted as therapists, paraprofessionals, and lay leaders have been effective in supporting cognitive-behavioural and self-care interventions (Foster et al., 2007; Montgomery et al., 2010).

The maximum weekly average contact time with the guide was 20 minutes, as used in a meta-analysis of depression self-care studies (Gellatly et al., 2007). To allow for longer interventions, no limit was set on the number of contacts between support and participant. 
The mode of contact could be in-person, through email, voice-messaging, or over the telephone (Tate and Zabinski, 1993).

Study samples were restricted to non-institutionalised adults. Studies recruiting participants both in a clinical setting and on a volunteer basis were included. Excluded were studies of children under the age of 18 exclusively, pregnant women, persons with psychotic mental disorders, and bipolar syndrome, as these studies often did not fit into the intervention design criteria, and unnecessarily inflated the number of studies found through the search strategy.

\section{Study screening}

Titles and abstracts were screened by the first author, and potentially eligible studies were identified and retained. Retained references were read in full text, using an inclusion and exclusion criteria form detailed above. All included studies were reviewed by the second author. In the event that it was not clear whether to include a given study, the study was discussed with the second author, until agreement was reached.

\section{Data extraction}

A standardised data extraction form was devised for the purposes of this review following pilot testing on 10 articles. Data were extracted twice on different occasions by the first author. Authors were contacted if necessary information was missing or needed clarification $(N=6)$. Data were extracted only from those intervention arms that provided a supported self-care intervention. If a study had two relevant intervention arms, data were extracted from both.

\section{Participant recruitment and characteristics}

Recruitment was classified as 'clinical', 'volunteer', or 'mixed'. Clinical recruitment was defined as the referral of patients to the study from either a primary care physician or mental health centre waiting list. Volunteer recruitment was defined as the recruitment of participants through advertisements in health-related websites, community centres, and newspapers. Mixed recruitment used both clinical and volunteer strategies. Where available, the following participant characteristics were abstracted: sex; age; per cent of participants married or cohabiting; and educational attainment.

\section{Self-care tool design}

The design of the self-care tools was classified as print-based, internet-based, or sequential internet/computer-based (modules of the self-care tool were made available to the participant sequentially, and in a specific order). By contrast, non-sequential designs allowed for modules to be completed at the discretion of the participant.

\section{Self-care guide background and role}

Guide background was recorded where stated. The role of the guide was classified as either non-clinical or clinical according to the following criteria. A non-clinical role was defined as limited to providing risk assessment, encouragement and moral support, and answering basic questions about the self-care tools, but not engaging in active therapy. A clinical role was defined providing feedback based on professional knowledge and, when required, brief therapy, in addition to non-clinical tasks.

Health Education Journal. Author's manuscript. Available at eScholarship@McGill 
The mode of patient contact refers to the medium of communication between guide and patient (telephone, in person or email).

The frequency of contact was the number of contacts between guide and patient reported by the study. Studies wherein guides corresponded with patients were classified as 'continuous', as there was no set number of contacts that were planned. Frequency of contact was either reported as the number of contacts that occurred during the intervention (using 'measures of adherence' below) or the number of intended contacts, as specified in the manuscript.

Measures of adherence to self-care intervention were classified into quantity of adherence, which describe how much of the tool participants completed, and quality of adherence, which describe how the participants used the self-care tool (Gould and Clum, 1993; Kazantzis et al., 2000, 2004).

\section{Quantity of adherence measures}

1. Per cent of completion: per cent of participants in a given intervention arm who have completed all modules of the self-care tool.

2. Mean or median completion: percentage of the self-care tool that was completed by the average participant in the intervention arm in question. Where not reported explicitly, this measure was calculated based on information provided on the percentage of participants completing each module.

\section{Quality of adherence measures}

1. Exercises per week: the number of exercises found in the self-care tool used per week by the average participant in the intervention.

2. Plans to continue use: percentage of participants who self-report plans to continue using the self-care tool after the adherence was measured.

3. Log ins per week: the average number of times participants logged in to an online self-care tool.

The time and source of adherence was recorded; self-reported adherence was classified as either post-treatment or continuous, the latter indicating assessment at more than one time point. Automated adherence was recorded through internet monitoring; direct observation was recorded in study clinics.

\section{RESULTS}

The study selection flow for this review chart is presented in Figure 1. The main reason for the exclusion of 82 studies was that the level of support was judged beyond the scope of self-care (31 studies): examples included stepped-care interventions, group therapy, or individual psychotherapy where support, rather than self-care, was the focus of the intervention. Fifteen interventions involved delivery of self-care learning resources, but had no support component. Among the 35 studies of supported self-care interventions, more than 50\% (18) did not report adherence. None of the included studies reported adherence in the abstract, nor was it included as a keyword.

Health Education Journal. Author’s manuscript. Available at eScholarship@McGill 
The two most commonly reported adherence measures were per cent of completion (per cent of participants who completed the entirety of the self-care tool offered) and mean completion (the average per cent of the intervention completed by participants). The distributions of per cent and mean completion levels in each study are shown in Figure 2. Per cent of completion rates ranged from 20\% to 93\% with a median of $70 \%$ in 20 intervention arms and a mean of $66 \%$ (SD 17). Mean completion ranged from $50.6 \%$ to $95.4 \%$ in 15 intervention arms with a median of $83 \%$ and a mean of $80 \%$ (SD 11.6). The number of self-care exercises completed per week (for example, mood-monitoring) was reported three times; log ins per week and per cent of participants planning to continue selfcare tool use were both reported twice (Table 1). Frequency of contact between the self-care guide and the participant was reported as the mean number of contacts per week or month, in four of 22 studies, shown in Table 1 (Mead et al., 2005; Osgood-Hynes et al., 1998; Perini et al., 2009; Titov et al., 2010). The remaining studies reported the planned, rather than actual, frequency of contact. Adherence measures did not make assumptions about the adherence of study drop-outs, who were counted as missing.

Study characteristics are displayed in Table 2. The majority of studies (16 of 22) recruited through media outlets using volunteer participants. In all but two studies the average participant age was below 50 . In $75 \%$ of studies the majority of participants were female. Three studies reported associations between participant characteristics and adherence. One study reported that patients with or without major depression were equally likely to have read or viewed the materials (Robinson et al., 1997). A second found no differences between self-care tool completers and non-completers on age, duration of problem, severity of anxiety, severity of depression, or sex (Learmonth et al., 2008). A third reported that married participants were more likely than non-married to complete the entire tool (66\% compared to $40 \%, P=0.008$ ), but found no differences in employment status, sick leave days, age, alcohol consumption and education (van Straten et al., 2008).

Table 1 describes the interventions used in the 22 studies (24 intervention arms). Sixteen intervention arms (14 studies) were electronic sequentially completed self-care tools. These were divided into two categories: internet-based sequential self-care tools which were accessed from home by participants (12 intervention arms), and computerbased sequential self-care tools which were only accessible at a mental health clinic (four intervention arms). These types of interventions presented successive modules based on completion of previous modules (Andersson et al., 2005, 2006; Carlbring et al., 2006, 2007; Furmark et al., 2009; Kaldo et al., 2008; Perini et al., 2009; Titov et al., 2010; van Straten et al., 2008) or on a weekly basis (Grime, 2004; Learmonth et al., 2008; Lorig et al., 2008; Shapiro et al., 2004; Whitfield et al., 2006). One study provided internet-accessed self-care tools, where all materials were simultaneously available (Berman et al., 2009). Print-based self-care tools were provided in seven studies (Bilich et al., 2008; Floyd et al., 2004; Jamison and Scogin, 1995; Johnston et al., 2010; Mead et al., 2005), two of which also provided video material (Osgood-Hynes et al., 1998; Robinson et al., 1997). Communication with participants occurred: through email and telephone for internet-based 
self-care tools; in person for computer-based interventions where the guide was present at the health clinic where the self-care tool was accessed; and over the telephone for the support of those using print-based self-care tools.

Quality of adherence was reported by seven studies: three studies reported number of self-care exercises completed per week; here, the implementation of self-care techniques was measured (Bilich et al., 2008; Jamison and Scogin, 1995; Mead et al., 2005). Four studies reported comprehension of self-care material (Floyd et al., 2004; Jamison and Scogin, 1995; Johnston et al., 2010; Whitfield et al., 2006). Quality of adherence was tacitly measured in six studies using automated adherence to track their patients' progress, whereby the guide verified that the participant had both completed and understood the material covered in the module in question (Andersson et al., 2005, 2006; Carlbring et al., 2006, 2007; Furmark et al., 2009; Kaldo et al., 2008). The remaining studies did not incorporate quality into their adherence measures. Three internet-based studies reported that successive modules were released to the participant upon completion of a previous module, but criteria for completing a module were not explained (Perini et al., 2009; Titov et al., 2010; van Straten et al., 2008). Similarly, the study by Lorig et al. (2008) measured how many modules the participant began using, as well as logins per week, but did not report how much of each module was actually completed; instead, it reported how many modules were participated in. Finally, one study combined automated and self-report adherence measures, obtaining a log in per week measure as well as a plan-to-continue statement (Berman et al., 2009). All studies reporting direct observation adherence, save Whitfield et al. (2006), also have the same ambiguity as to whether completion or participation was measured; these studies also all offered the same computerised intervention (Grime, 2004; Learmonth et al., 2008; Shapiro et al., 2004).

\section{DISCUSSION}

The present review aimed to identify original studies of supported self-care interventions for depression or anxiety to determine: the proportion that reported adherence to the intervention; the types of adherence measures used, participant characteristics associated with adherence, and the levels of adherence reported. To date, adherence to selfcare tools has not been emphasised in many studies of supported self-care. Roughly half of those studies identified with the search strategy did not report adherence. When reported, it was never included in the abstract, and the studies were not assigned adherence keywords for database indexing.

The observed levels of adherence, when available, indicate that, among half or more of the intervention arms studied, $70 \%$ of participants completed the entirety of the self-care tools offered, and that participants completed an average of $83 \%$ of the self-care tools. The median rate of adherence identified in the present review is higher than that reported in an earlier review of computerised CBT interventions for depression or anxiety, in which a median per cent completion of 56\% was derived from 36 individual studies; mean completion was not reported (Waller and Gilbody, 2004). The review included studies up to 
July of 2005 (Waller and Gilbody, 2004), and it is plausible that the increased prominence of the internet in the five years since that report could help explain the higher reported adherence found in the present study. Median per cent completion adherence in the current review also appears to be higher than in a review of internet-only supported or unsupported self-care studies for depression and anxiety (Christensen, 2009). Taken together, reported adherence levels appear to be fairly high, indicating a significant amount of patient involvement in the interventions. Researchers can use the adherence information compiled here - along with the intervention descriptions - to aid in the planning phase of a supported self-care intervention, or to compare with their adherence results. Only four studies reported adherence to the self-care support component; similarly, only three studies reported univariate associations between participant characteristics and higher adherence. Therefore, no conclusions may yet be drawn based on the data currently available.

Organisations providing supported self-care interventions should be encouraged by the results presented in this study, which indicate that participants are opting to use significant portions of their self-care tools, and may therefore be learning the self-care techniques instructed therein, leading to positive health outcomes. Some methodological improvements, however, are needed to improve our understanding of adherence in this field. Only four of 22 studies reported adherence to the support component of the intervention; as such, we do not know how much people are opting to use the support component of the intervention. Questions remain, however, including: is the use of the selfcare tool correlated with use of the support component; and is the use of the support component related to treatment outcome?

Adherence was most frequently measured as per cent completion of the self-care tool, which is a binary measure of tool completion that gives no information about how much of the self-care tool was completed by participants who did not complete the tool in its entirety. Moreover, quantity of adherence was reported more frequently than quality of adherence. Quality of adherence measurement allows researchers and clinicians to gauge how the participants are using the tools, including the frequency of use, and their understanding and employment of the techniques therein.

Accuracy is also a shortcoming when adherence is self-reported, as occurs in any non-electronic intervention. A review of adherence reporting to homework assignments in psychotherapy for psychiatric patients recommended recording adherence at multiple timepoints during the intervention, and from more than one source (Kazantzis et al., 2004), which could improve the accuracy of reported adherence, and allow early identification of non-adherers (Bilich et al., 2008; Kazantzis et al., 2004). In the present review, all but one study (Berman et al., 2009) obtained adherence information from a single source: selfreport, automated records, or self-care guide assessments. Among studies using nonautomated or direct observation adherence assessment, all but two recorded adherence at post-treatment interviews.

Findings from the present review are subject to some limitations. Although the selection of studies was reviewed by two of us (first and second authors), data were 
extracted only by the first author, which could have resulted in some error; however, care was taken to re-verify the extracted data at least twice per selected study. Generalisability of the findings is limited, as the majority of studies recruited volunteers through media outlets, and had a majority of female participants. Direct comparisons of adherence between interventions should be made with caution due to the diversity of self-care tool content. To improve upon the current research, a number of methodological components may be improved. Reporting adherence to interventions of supported self-care for mental illness should be standard practice, and should use descriptive summary measures of tool completion (mean or median completion). Adherence to the self-care guide should also be reported to gauge participants' use of the support component. Thorough descriptions of intervention components should be provided in order to contextualise the interventions within the larger body of research. Whileadherence reporting has thus far largely focused on the amount (quantity) of the self-care tool completed, there are a number of other dimensions that might also be measured (e.g. frequency of use, total time spent per week, comprehension of self-care concepts, and use of self-care exercises). These elements of the quality of adherence would provide a more complete understanding of whether and how adherence may be related to better outcomes, and can be assessed either by the guide or during study interviews (Kazantzis et al., 2004). By implementing improvements, future researchers and clinical practitioners of supported self-care will be provided with benchmarks for comparing adherence.

The accuracy of adherence reporting can also be improved. Given the increasing prominence of internet-based computing (including mobile technology), computerised selfcare tools allow for detailed adherence data to be collected continually, and with little added expense. Internet software allows for real-time and accurate 'automated' measurement of adherence. Where automated measures of adherence are not available, adherence should be assessed - perhaps with the aid of the self-care guide - at more than one time-point to avoid recall bias at post-treatment.

Finally, self-care studies should explore the relationship between adherence to the intervention and the primary outcome of the intervention. A positive correlation has been repeatedly shown in individual studies and in meta-analyses of adherence to homework assignments in psychotherapy (largely for depression or anxiety), adherence to nonpsychiatric medical treatments, and in a limited number of supported self-care studies (Kazantzis et al., 2000; DiMatteo et al., 2002; Donkin, 2011). Further research in this field will aid our understanding of the treatment-effect relationship for supported self-care interventions.

\section{Acknowledgements}

Simco conducted the review in partial requirements for a Masters degree in Epidemiology at McGill University. McCusker supervised the research and assisted with screening studies for relevance. Sewitch co-supervised the research. All authors contributed to writing the paper and approved it before submission.

Health Education Journal. Author's manuscript. Available at eScholarship@McGill 


\section{Figure 1. Study flow diagram}

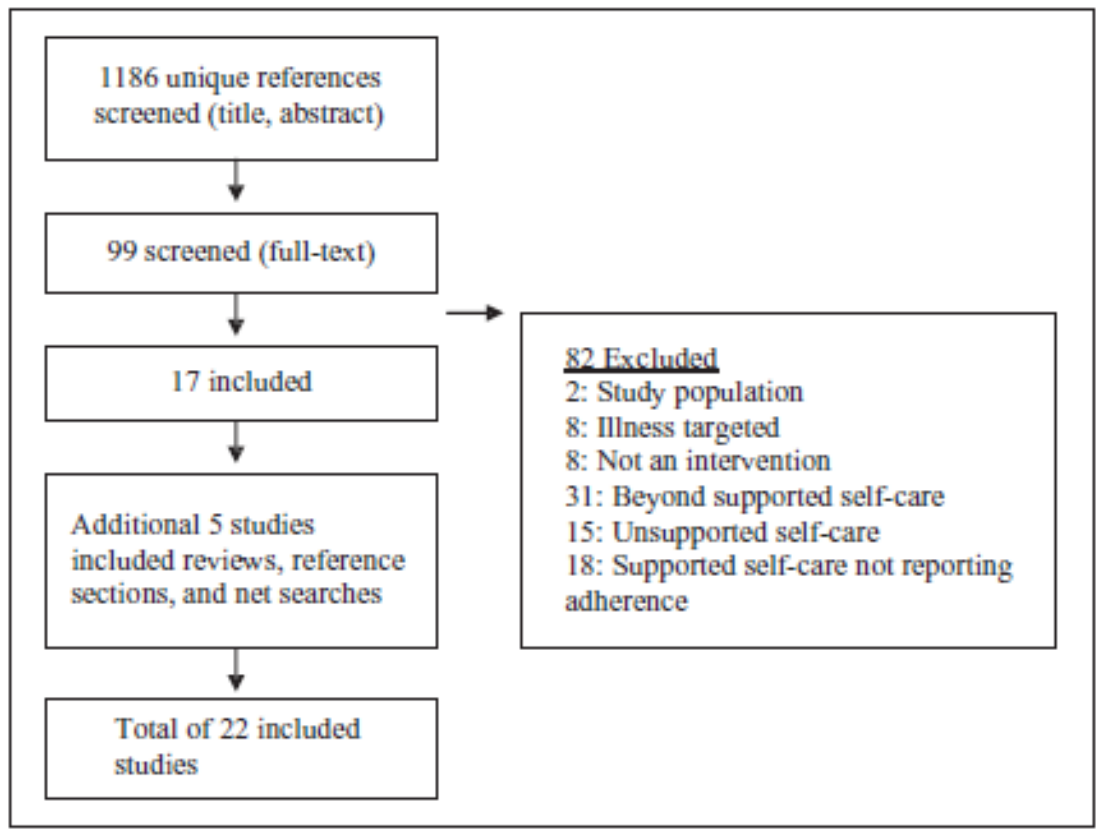

Figure 2. Per cent and mean completion of self-care tools

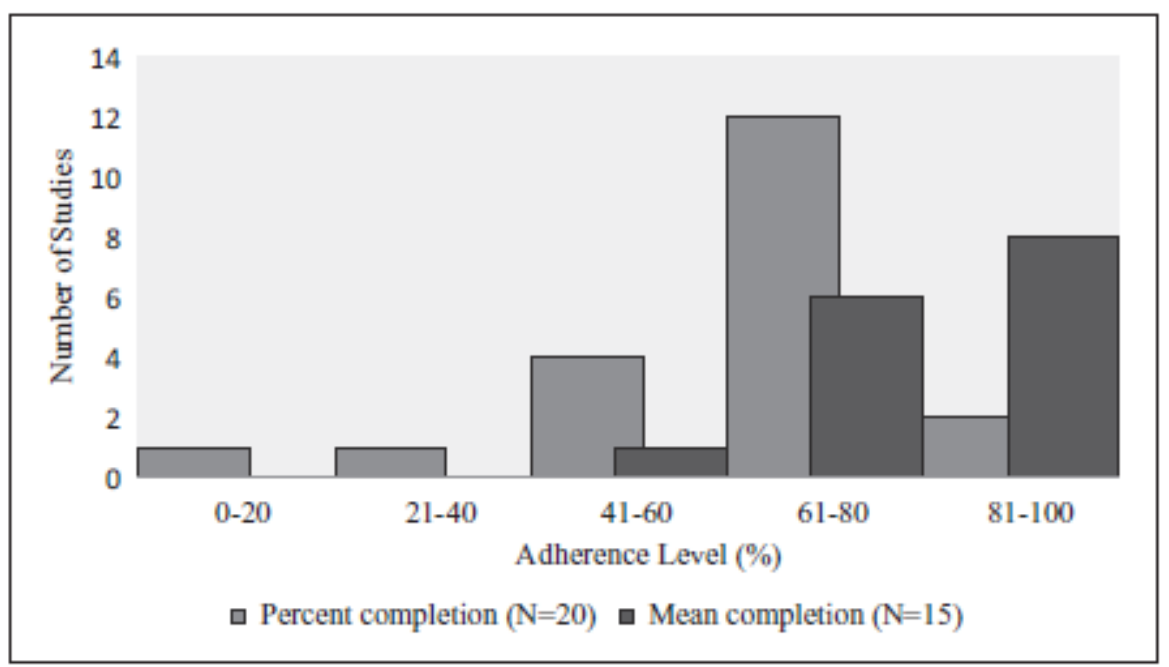




\begin{tabular}{|c|c|c|c|c|c|}
\hline Author, year, study design & $\begin{array}{l}\text { Self-care tools } \\
\text { content }\end{array}$ & Coach background (role) & $\begin{array}{l}\text { Mode of patient } \\
\text { contact }\end{array}$ & $\begin{array}{l}\text { Duration (weeks) } \\
\text { Frequency of } \\
\text { contact }\end{array}$ & Measure of Adherence \\
\hline $\begin{array}{l}\text { Andersson et al., } \\
\text { 2005[25]; RCT }\end{array}$ & $\begin{array}{l}\text { Internet-based } \\
\text { sequential CBT }\end{array}$ & $\begin{array}{l}\text { Post-graduate therapist } \\
\text { (clinical) }\end{array}$ & E-mail & 10 Weekly contact & $\begin{array}{l}\text { Automated: } \\
\text { PC: } 65 \% \\
\text { MC: } 74 \%\end{array}$ \\
\hline $\begin{array}{l}\text { Andersson et al., } \\
\text { 2006[26]; RCT }\end{array}$ & $\begin{array}{l}\text { Internet-based } \\
\text { sequential CBT }\end{array}$ & $\begin{array}{l}\text { Clinical psychologists and } \\
\text { Master’s level student } \\
\text { psychologists (clinical) }\end{array}$ & E-mail & $\begin{array}{l}9 \text { Continuous } \\
\text { contact }\end{array}$ & $\begin{array}{l}\text { Automated: } \\
\text { PC: } 58.1 \% \\
\text { MC: } 86.7 \%\end{array}$ \\
\hline $\begin{array}{l}\text { Berman et al., 2009[35] } \\
\text { RCT }\end{array}$ & $\begin{array}{l}\text { Internet-based mind- } \\
\text { body \& comple- } \\
\text { mentary alternative } \\
\text { medicine }\end{array}$ & $\begin{array}{l}\text { Research assistant } \\
\text { (non- clinical) }\end{array}$ & E-mail & $\begin{array}{l}6 \text { Continuous } \\
\text { contact }\end{array}$ & $\begin{array}{l}\text { Automated: } \\
\text { 3.75 log-in/week } \\
\text { Self-report: post- } \\
\text { treatment PCU: 78\% }\end{array}$ \\
\hline $\begin{array}{l}\text { Bilich et al., 2008[36]; } \\
\text { RCT; Minimal contact } \\
\text { arm }\end{array}$ & $\begin{array}{l}\text { Print-based CBT } \\
1 \text { Workbook }\end{array}$ & $\begin{array}{l}\text { Research assistant } \\
\text { (non-clinical) }\end{array}$ & Telephone & 8 Weekly contact & $\begin{array}{l}\text { Self-report: } \\
\text { continuous PC: 85\% } \\
\text { EPW: } 2\end{array}$ \\
\hline $\begin{array}{l}\text { Bilich et al., 2008[36]; } \\
\text { RCT; Assisted self-help } \\
\text { arm }\end{array}$ & $\begin{array}{l}\text { Print-based CBT } \\
1 \text { Workbook }\end{array}$ & $\begin{array}{l}\text { Psychologist or intern } \\
\text { psychologist (clinical) }\end{array}$ & Telephone & 8 Weekly contact & $\begin{array}{l}\text { AS ABOVE - } \\
\text { adherence pooled for } \\
\text { both intervention arms }\end{array}$ \\
\hline $\begin{array}{l}\text { Carlbring et al., 2006[27]; } \\
\text { RCT }\end{array}$ & $\begin{array}{l}\text { Internet-based } \\
\text { sequential CBT }\end{array}$ & $\begin{array}{l}\text { Master's level student } \\
\text { psychologists (clinical) }\end{array}$ & E-mail; telephone & 10 Weekly contact & $\begin{array}{l}\text { Automated: } \\
\text { PC: } 80 \% \\
\text { MC: } 89 \%\end{array}$ \\
\hline $\begin{array}{l}\text { Carlbring et al., 2007[28]; } \\
\text { RCT }\end{array}$ & $\begin{array}{l}\text { Internet-based } \\
\text { sequential CBT }\end{array}$ & $\begin{array}{l}\text { Master's level student } \\
\text { psychologists (clinical) }\end{array}$ & E-mail; telephone & 9 Weekly contact & $\begin{array}{l}\text { Automated: } \\
\text { PC: } 93 \% \\
\text { MC: } 95.4 \%\end{array}$ \\
\hline $\begin{array}{l}\text { Floyd et al, 2004[37]; } \\
\text { RCT }\end{array}$ & $\begin{array}{l}\text { Print-based CBT } \\
\text { Book }\end{array}$ & Psychologist (clinical) & Telephone & 4 Weekly contact & $\begin{array}{l}\text { Self-report: } \\
\text { continuous } \\
\text { MC: } 63.8 \%\end{array}$ \\
\hline $\begin{array}{l}\text { Furmark et al., 2009[29]; } \\
\text { RCT; CBT arm }\end{array}$ & $\begin{array}{l}\text { Internet-based } \\
\text { sequential CBT }\end{array}$ & $\begin{array}{l}\text { Master's level student } \\
\text { psychologists } \\
\text { (clinical) }\end{array}$ & E-mail & $\begin{array}{l}9 \text { Continuous } \\
\text { contact }\end{array}$ & $\begin{array}{l}\text { Automated: } \\
\text { PC: } 34.50 \% \\
\text { MC: } 77.3 \%\end{array}$ \\
\hline $\begin{array}{l}\text { Furmark et al., 2009[29]; } \\
\text { RCT; Relaxation arm }\end{array}$ & $\begin{array}{l}\text { Internet-based } \\
\text { sequential relaxation }\end{array}$ & $\begin{array}{l}\text { Master's level student } \\
\text { psychologists } \\
\text { (clinical) }\end{array}$ & E-mail & $\begin{array}{l}9 \text { Continuous } \\
\text { contact }\end{array}$ & $\begin{array}{l}\text { Automated: } \\
\text { PC: } 53.60 \% \\
\text { MC: } 75.1 \%\end{array}$ \\
\hline Grime et al., 2004[31]; & $\begin{array}{l}\text { Computer-based } \\
\text { sequential CBT }\end{array}$ & Administrator (non- & In-person & 8 Contact upon use & $\begin{array}{l}\text { Direct observation: } \\
\text { PC: } 66.6 \%\end{array}$ \\
\hline
\end{tabular}




\begin{tabular}{|c|c|c|c|c|c|}
\hline Author, year, study design & $\begin{array}{l}\text { Self-care tools } \\
\text { content }\end{array}$ & Coach background (role) & $\begin{array}{l}\text { Mode of patient } \\
\text { contact }\end{array}$ & $\begin{array}{l}\text { Duration (weeks) } \\
\text { Frequency of } \\
\text { contact }\end{array}$ & Measure of Adherence \\
\hline RCT & $(\mathrm{BtB})$ & clinical) & & of tool at clinic & MC: $79.7 \%$ \\
\hline $\begin{array}{l}\text { Jamison et al., 1995[38]; } \\
\text { RCT }\end{array}$ & $\begin{array}{l}\text { Print-based CBT } \\
\text { Book }\end{array}$ & $\begin{array}{l}\text { Research assistant (non- } \\
\text { clinical) }\end{array}$ & Telephone & 4 Weekly contact & $\begin{array}{l}\text { Self-report: post- } \\
\text { treatment } \\
\text { MC: } 83.75 \% \\
\text { EPW: } 0.86\end{array}$ \\
\hline $\begin{array}{l}\text { Johnston et al., 2010[39]; } \\
\text { RCT }\end{array}$ & $\begin{array}{l}\text { Paper-based CBT } \\
1 \text { workbook; } 6 \\
\text { modules }\end{array}$ & $\begin{array}{l}\text { Master's level social } \\
\text { sciences student (non- } \\
\text { clinical) }\end{array}$ & Telephone & 6 Weekly contact & $\begin{array}{l}\text { Self-report: post- } \\
\text { treatment } \\
\text { PC: } 72.6 \% \text { (mean } \\
\text { module PC) }\end{array}$ \\
\hline $\begin{array}{l}\text { Kaldo et al., 2008[30]; } \\
\text { RCT }\end{array}$ & $\begin{array}{l}\text { Internet-based } \\
\text { sequential CBT }\end{array}$ & $\begin{array}{l}\text { Master's level student } \\
\text { psychologists (clinical) }\end{array}$ & E-mail & $\begin{array}{l}6 \text { Continuous } \\
\text { contact }\end{array}$ & $\begin{array}{l}\text { Automated: PC: } 62 \% \\
\text { MC: } 75 \%\end{array}$ \\
\hline $\begin{array}{l}\text { Learmonth et al., } \\
\text { 2008[23]; Clinical audit }\end{array}$ & $\begin{array}{l}\text { Computer-based } \\
\text { sequential CBT } \\
(\mathrm{BtB})\end{array}$ & $\begin{array}{l}\text { Administrator (non- } \\
\text { clinical) }\end{array}$ & In-person & $\begin{array}{l}7 \text { Contact upon use } \\
\text { of tool at clinic }\end{array}$ & $\begin{array}{l}\text { Direct observation: } \\
\text { PC: } 71 \% \\
\text { MC: } 83.75 \%\end{array}$ \\
\hline $\begin{array}{l}\text { Lorig et al., 2008[32]; } \\
\text { Single-arm }\end{array}$ & $\begin{array}{l}\text { Internet-based } \\
\text { sequential CBT and } \\
\text { self-management }\end{array}$ & $\begin{array}{l}\text { Peers from expert-patient } \\
\text { program (non- clinical) }\end{array}$ & E-mail & $\begin{array}{l}6 \text { Continuous } \\
\text { contact }\end{array}$ & $\begin{array}{l}\text { Automated } \\
\text { PC: } 79 \% \\
\text { MC: } 86.7 \%\end{array}$ \\
\hline $\begin{array}{l}\text { Mead et al., } \\
\text { 2005[18];RCT }\end{array}$ & $\begin{array}{l}\text { Print-based CBT } \\
1 \text { workbook }\end{array}$ & $\begin{array}{l}\text { Therapist assistant } \\
\text { (clinical) }\end{array}$ & In-person & $\begin{array}{l}12 \text { Contact at study } \\
\text { clinic } \\
\text { Mean } 1.05 \text { contact } \\
\text { per month }\end{array}$ & $\begin{array}{l}\text { Self report: post- } \\
\text { treatment } \\
88 \% \text { Completed } \geq \\
\text { half of tool } \\
\text { EPW: } 52 \% \geq 1 \text { PCU: } \\
90 \%\end{array}$ \\
\hline $\begin{array}{l}\text { Osgood-Hynes et al, } \\
\text { 1998[19]; RCT }\end{array}$ & $\begin{array}{l}\text { Print-based and } \\
\text { video CBT } 3 \\
\text { workbooks }\end{array}$ & $\begin{array}{l}\text { Interactive voice response } \\
\& \text { voice-mail with } \\
\text { clinicians (clinical) }\end{array}$ & $\begin{array}{l}\text { Telephone } \\
\text { automated }\end{array}$ & $\begin{array}{l}12 \text { Mean } 1.1 \\
\text { contact per week }\end{array}$ & $\begin{array}{l}\text { Self-report: post- } \\
\text { treatment } \\
\text { PC: } 20 \% \text { MC: } 50.6 \% \\
\text { (for all } 3 \text { workbooks) }\end{array}$ \\
\hline $\begin{array}{l}\text { Perini et al., 2009[20]; } \\
\text { RCT }\end{array}$ & $\begin{array}{l}\text { Internet-based } \\
\text { sequential CBT }\end{array}$ & $\begin{array}{l}\text { Psychiatrist } \\
\text { (clinical) }\end{array}$ & E-mail & $\begin{array}{l}8 \text { Continuous } \\
\text { contact: mean } 1 \\
\text { contact per week }\end{array}$ & $\begin{array}{l}\text { Automated: } \\
\text { PC: } 74 \%\end{array}$ \\
\hline $\begin{array}{l}\text { Robinson et al., 1997[22]; } \\
\text { RCT }\end{array}$ & $\begin{array}{l}\text { Print-based and } \\
\text { video CBT } 2 \\
\text { workbooks }\end{array}$ & $\begin{array}{l}\text { FP and Psychiatrist at } \\
\text { HMO (clinical) }\end{array}$ & In-person & $\begin{array}{l}282 \text { visits to FP; } \\
2 \text { visits to } \\
\text { psychiatrist }\end{array}$ & $\begin{array}{l}\text { Self-report: post- } \\
\text { treatment } \\
\text { PC: } 75 \% \text { for all tools }\end{array}$ \\
\hline
\end{tabular}




\begin{tabular}{|c|c|c|c|c|c|}
\hline Author, year, study design & $\begin{array}{l}\text { Self-care tools } \\
\text { content }\end{array}$ & Coach background (role) & $\begin{array}{l}\text { Mode of patient } \\
\text { contact }\end{array}$ & $\begin{array}{l}\text { Duration (weeks) } \\
\text { Frequency of } \\
\text { contact }\end{array}$ & Measure of Adherence \\
\hline $\begin{array}{l}\text { Shapiro et al., 2004[33]; } \\
\text { Clinical Audit }\end{array}$ & $\begin{array}{l}\text { Computer-based } \\
\text { sequential CBT } \\
(\mathrm{BtB})\end{array}$ & $\begin{array}{l}\text { Administrator } \\
\text { (non-clinical) }\end{array}$ & In-person & $\begin{array}{l}8 \text { Contact upon use } \\
\text { of tool at clinic }\end{array}$ & $\begin{array}{l}\text { Direct observation: } \\
\text { PC: } 54.80 \%\end{array}$ \\
\hline $\begin{array}{l}\text { Titov et al., 2010[21]; } \\
\text { Technician-assisted arm; } \\
\text { RCT }\end{array}$ & $\begin{array}{l}\text { Internet-based } \\
\text { sequential CBT }\end{array}$ & $\begin{array}{l}\text { Administrator } \\
\text { (non-clinical) }\end{array}$ & $\begin{array}{l}\text { E-mail or } \\
\text { Telephone }\end{array}$ & $\begin{array}{l}8 \text { Continuous } \\
\text { contact: Mean } 4.6 \\
\text { contact per week }\end{array}$ & $\begin{array}{l}\text { Automated: } \\
\text { PC: } 80 \% \\
\text { MC: } 92.7 \%\end{array}$ \\
\hline $\begin{array}{l}\text { Titov et al., 2010[21]; } \\
\text { Clinician-assisted arm; } \\
\text { RCT }\end{array}$ & $\begin{array}{l}\text { Internet-based } \\
\text { sequential CBT }\end{array}$ & Psychiatrist (clinical) & $\begin{array}{l}\text { E-mail or } \\
\text { Telephone }\end{array}$ & $\begin{array}{l}8 \text { Continuous } \\
\text { contact: Mean } 4.3 \\
\text { contact per week }\end{array}$ & $\begin{array}{l}\text { Automated: } \\
\text { PC: } 70 \% \\
\text { MC: } 88.7 \%\end{array}$ \\
\hline $\begin{array}{l}\text { Van Straten et al., } \\
\text { 2008[24]; RCT }\end{array}$ & $\begin{array}{l}\text { Internet-based } \\
\text { sequential CBT }\end{array}$ & $\begin{array}{l}\text { Master's level student } \\
\text { psychologists (clinical) }\end{array}$ & E-mail & $\begin{array}{l}4 \text { Continuous } \\
\text { contact }\end{array}$ & $\begin{array}{l}\text { Automated: } \\
\text { PC: } 55 \%\end{array}$ \\
\hline $\begin{array}{l}\text { Whitfield et al., 2006[34]; } \\
\text { Single-arm }\end{array}$ & $\begin{array}{l}\text { Computer-based } \\
\text { sequential CBT }\end{array}$ & $\begin{array}{l}\text { Psychiatric nurse } \\
\text { (non-clinical) }\end{array}$ & In-person & $\begin{array}{l}6 \text { Contact upon use } \\
\text { of tool at clinic }\end{array}$ & $\begin{array}{l}\text { Direct Observation: } \\
\text { PC: } 70 \%\end{array}$ \\
\hline
\end{tabular}

CBT: cognitive/behavioral therapy; sequential self-care tools: modules are released to participants in pre-defined order; PC: percent completion of the entire self-care tool; MC: mean completion of the self-care tool; EPW: self-care tool exercises completed per week; PCU: plans to continue using the tool; clinical: clinical support provided; non-clinical: non-clinical support provided; BtB: Beating the Blues intervention 


\section{REFERENCES}

1. Anderson L, Lewis G, Araya R, Elgie R, Harrison G, Proudfoot J, Schmidt U, Sharp D, Weightman A and Williams C (2005) Self-help books for depression: How can practitioners and patients make the right choice? The British Journal of General Practice 55(514): 387-92.

2. Andersson G, Bergström J, Holländare F, Carlbring P, Kalso V and Ekselius L (2005) Internetbased self-help for depression: Randomised controlled trial. The British Journal of Psychiatry 187(5): 456-61.

3. Andersson G, Carlbring P, Holmström A, Sparthan E, Furmark T, Nilsson-Ihrfelt E, Buhrman $M$ and Ekselius L (2006) Internet-based self-help with therapist feedback and in vivo group exposure for social phobia: A randomized controlled trial. Journal of Consulting and Clinical Psychology 74(4): 677-86.

4. Berman RL, Iris MA, Bode R and Drengenberg C (2009) The effectiveness of an online mindbody intervention for older adults with chronic pain. Journal of Pain 10(1): 68-79.

5. Bilich LL, Deane FP, Phipps AB, Barisic M and Gould G (2008) Effectiveness of bibliotherapy self-help for depression with varying levels of telephone helpline support. Clinical Psychology \& Psychotherapy 15(2): 61-74.

6. Bower P, Richards D and Lovell K (2001) The clinical and cost-effectiveness of self-help treatments for anxiety and depressive disorders in primary care: A systematic review. The British Journal of General Practice 51(471): 838-45.

7. Carlbring P, Bohman S, Brunt S, Buhrman M, Westling BE, Ekselius L and Andersson G (2006) Remote treatment of panic disorder: A randomized trial of internet-based cognitive behavior therapy supplemented with telephone calls. The American Journal of Psychiatry 163(12): 2119-25.

8. Carlbring P, Gunnarsdottir M, Hedensjo L, Andersson G, Ekselius L and Furmark T (2007) Treatment of social phobia: Randomised trial of internet-delivered cognitive-behavioural therapy with telephone support. The British Journal of Psychiatry 190: 123-8.

9. Christensen H (2009) Adherence in internet interventions for anxiety and depression: Systematic review. Journal of Medical Internet Research 11(2): e13.

10. Den Boer P, Wiersma D and Van den Bosch RJ (2004) Why is self-help neglected in the treatment of emotional disorders? A meta-analysis. Psychological Medicine 34(6): 959-71.

11. DiMatteo MR, Giordani PJ, Lepper HS and Croghan TW (2002) Patient adherence and medical treatment outcomes: A meta-analysis. Medical Care 40(9): 794-811.

12. DiMatteo MR, Haskard KB and Williams SL (2007) Health beliefs, disease severity, and patient adherence: A meta-analysis. Medical Care 45(6): 521-8.

13. DiMatteo MR (2004) Social support and patient adherence to medical treatment: A metaanalysis. Health Psychology 23(2): 207-18.

14. Donkin L (2011) A systematic review of the impact of adherence on the effectiveness of etherapies. Journal of Medical Internet Research 13(3): e52.

15. Floyd M, Scogin F, McKendree-Smith NL, Floyd DL and Rokke PD (2004) Cognitive therapy for depression. Behavior Modification 28(2): 297-318.

16. Foster G, Taylor SJ, Eldridge SE, Ramsay J and Griffiths CJ (2007) Self-management education programmes by lay leaders for people with chronic conditions. Cochrane Database of Systematic Reviews (4). Available at: http://www.mrw.interscience.wiley.com/cochrane/clsysrev/articles/CD005108/frame.html (accessed 1 October 2013). 
17. Furmark T, Carlbring P, Hedman E, Sonnenstein A, Clevberger P, Bohman B, Eriksson A, Hållén A, Frykman M, Holmström A, Sparthan E, Tillfors M, Ihrfelt EN, Spak M, Ekselius L and Andersson G (2009) Guided and unguided self-help for social anxiety disorder: Randomised controlled trial. The British Journal of Psychiatry 5: 440-7.

18. Gellatly J, Bower P, Hennessy S, Richards D, Gilbody S and Lovell K (2007) What makes selfhelp interventions effective in the management of depressive symptoms? Meta-analysis and meta-regression. Psychological Medicine 37(9): 1217-28.

19. Gould RA and Clum GA (1993) A meta-analysis of self-help treatment approaches. Clinical Psychology Review 13(2): 169-86.

20. Grime PR (2004) Computerized cognitive behavioural therapy at work: A randomized controlled trial in employees with recent stress-related absenteeism. Occupational Medicine 54(5): 353-9.

21. Jamison C and Scogin F (1995) The outcome of cognitive bibliotherapy with depressed adults. Journal of Consulting and Clinical Psychology 63(4): 644-50.

22. Johnston M, Foster M, Shennan J, Starkey NJ and Johnson A (2010) The effectiveness of an acceptance and commitment therapy self-help intervention for chronic pain. The Clinical Journal of Pain 26(5): 393-402.

23. Kaldo V, Levin S, Widarsson J, Buhrman M, Larsen HC and Andersson G (2008) Internet versus group cognitive-behavioral treatment of distress associated with tinnitus: A randomized controlled trial. Behavior Therapy 39(4): 348-59.

24. Kazantzis N, Deane FP and Ronan KR (2004) Assessing compliance with homework assignments: Review and recommendations for clinical practice. Journal of Clinical Psychology 60(6): 627-41.

25. Kazantzis N, Deane FP and Ronan KR (2000) Homework assignments in cognitive and behavioral therapy: A meta-analysis. Clinical Psychology: Science and Practice 7(2): 189202.

26. Learmonth D, Trosh J, Rai S and Sewell J (2008) Cavanagh K. The role of computer-aided psychotherapy within an nhs cbt specialist service. Counselling and Psychotherapy Research 8(2): 117-23.

27. Lorig KR, Ritter PL, Dost A, Plant K, Laurent DD and McNeil I (2008) The expert patients programme online, a 1-year study of an internet-based self-management programme for people with long-term conditions. Chronic Illness 4(4): 247-56

28. Mead N, MacDonald W, Bower P, Lovell K, Richards D, Roberts C and Bucknall A (2005) The clinical effectiveness of guided self-help versus waiting-list control in the management of anxiety and depression: A randomized controlled trial. Psychological Medicine 35(11): 1633-43.

29. Montgomery EC, Kunik ME, Wilson N, Stanley MA and Weiss B (2010) Can paraprofessionals deliver cognitive-behavioral therapy to treat anxiety and depressive symptoms? Bulletin of the Menninger Clinic 74(1): 45-62.

30. National Collaborating Centre for Mental Health (2009) Depression: The treatment and management of depression in adults. London, UK: NHS,NICE Clinical guideline 90. Available at: http://guidance.nice.org.uk/CG90 (accessed 17 October 2013).

31. National Collaborating Centre for Mental Health (2011) Generalised anxiety disorder and panic disorder (with or without agoraphobia) in adults. London: NHS, NICE Clinical guideline 113. Available at: http://publications.nice.org.uk/generalised-anxiety-disorder-and-panicdisorder-with-or-without-agoraphobia-in-adults-cg113/guidance (accessed 17 October 2013). 
32. Newman MG, Erickson T, Przeworski A and Dzus E (2003) Self-help and minimal-contact therapies for anxiety disorders: Is human contact necessary for therapeutic efficacy? Journal of Clinical Psychology 59(3): 251-74.

33. Osgood-Hynes DJ, Greist JH, Marks IM, Baer L, Heneman SW, Wenzel KW, Manzo PA, Parkin JR, Spierings CJ, Dottl SL and Vitse HM (1998) Self-administered psychotherapy for depression using a telephone-accessed computer system plus booklets: An open U.S.U.K. Study. The Journal of Clinical Psychiatry 59(7): 358-65.

34. Perini S, Titov N and Andrews G (2009) Clinician-assisted internet-based treatment is effective for depression: Randomized controlled trial. Australian and New Zealand Journal of Psychiatry 43(6): 571-8.

35. Robinson P, Katon W, Von Korff M, Bush T, Simon G, Lin E and Walker E (1997) The education of depressed primary care patients: What do patients think of interactive booklets and a video? Journal of Family Practice 44(6): 562-71.

36. Sabate E (2003) Adherence to long-term therapies: Evidence for action. Geneva: WHO.

37. Shapiro DA, Bickerstaffe D and Cavanagh K (2004) Computerized cognitive-behaviour therapy for anxiety and depression: A practical solution to the shortage of trained therapists. Journal of Psychiatric and Mental Health Nursing 11(5): 508-13.

38. Tate DF and Zabinski MF (2004)Computer and internet applications for psychological treatment: Update for clinicians. Journal of Clinical Psychology 60(2): 209-20.

39. Titov N, Andrews G, Davies M, McIntyre K, Robinson E and Solley K (2010) Internet treatment for depression: A randomized controlled trial comparing clinician vs. Technician assistance. Public Library of Science One 5(6): e10939.

40. van Straten A, Cuijpers P and Smits N (2008) Effectiveness of a web-based self-help intervention for symptoms of depression, anxiety, and stress: Randomized controlled trial. Journal of Medical Internet Research 10(1): e7.

41. Waller R and Gilbody S (2009) Barriers to the uptake of computerized cognitive behavioural therapy: A systematic review of the quantitative and qualitative evidence. Psychological Medicine 39(5): 705-12.

42. Whitfield G, Hinshelwood R, Pashely A, Campsie L and Williams C (2006) The impact of a novel computerized cbt cd rom (overcoming depression) offered to patients referred to clinical psychology. Behavioural and Cognitive Psychotherapy 34(1): 1-11. 